\title{
Response of summer gujari rice to various establishment techniques and weed control methods on different yield attributes
}

\author{
R.R. SHEWALE \\ Department of Agronomy, Anand Agricultural University, ANAND (GUJARAT) INDIA
}

\begin{abstract}
An experiment was conducted during summer season of the year 2009-10 at Regional Research Station, Anand Agricultural University, Anand to assess the response of rice to establishment techniques and weed control methods. Results revealed that transplanting 10-12 days old seedling with spacing of $25 \times 25 \mathrm{~cm}, 1$ plant hill ${ }^{-1}$ [System of Rice Intensification (SRI)] + 100:25:00 kg NPK, $25 \mathrm{~kg} \mathrm{ZnSO}_{4} \mathrm{ha}^{-1}, 25$ per cent N from FYM recorded better results of yield attributes (i.e. effective tillers, panicles, grains, panicles length, panicles weight and test weight). Pyrazosulfuron and use of rotary weeder decreased weed intensity. However, the hand weedings were efficient.
\end{abstract}

Key Words : Establishment techniques, Weed control methods, yield attributes

View Point Article : Shewale, R.R. (2016). Response of summer gujari rice to various establishment techniques and weed control methods on different yield attributes. Internat. J. agric. Sci., 12 (1) : 148-150

Article History : Received : 20.12.2015; Accepted : 30.12 .2015 